\title{
ANALISIS PENGGUNAAN APLIKASI SIGOLABANG DALAM PENGELOLAAN BARANG MILIK DAERAH KOTA BANDA ACEH
}

\author{
Helmi \\ Dosen Ilmu Pemerintahan \\ Universitas Syiah Kuala \\ helmi fisip@unsyiah.ac.id
}

\author{
Adi Muzwardi \\ Dosen Ilmu Hubungan Internasional \\ Universitas Maritim Raja Ali Haji \\ ady1800@mail.unpad.ac.id
}

\author{
Effendi Hasan \\ Dosen Ilmu Politik \\ Universitas Syiah Kuala \\ effendi@unsyiah.ac.id
}

\begin{abstract}
Abstrak
Aplikasi Sigolabang merupakan aplikasi yang digunakan untuk mengelola barang milik daerah secara efektif dan efisien guna mendukung implementasi e-government. Pengelolaan Barang Milik Daerah dilaksanakan sesuai dengan ketentuan Peraturan Tata Usaha Nomor 7 Tahun 2018 tentang Pengelolaan Barang Milik Daerah di Banda Aceh. Namun dalam pelaksanaan rencana ini, karena keterbatasan pengalaman dan kemampuan aparatur, mereka menghadapi situasi yang bertentangan dengan prosedur yang ditetapkan oleh pemerintah daerah, atau lemahnya keterkaitan sumber daya manusia, infrastruktur, dan pemanfaatan aset daerah. Masih terdapat kendala dalam proses pengelolaan barang milik daerah di SKPK. Lebih produktif Tujuan dari penelitian ini adalah untuk mengidentifikasi dan menjelaskan analisis pengelolaan properti di Banda Aceh dengan menggunakan aplikasi Sigolabang. Pemerintah Kota Banda Aceh menghadapi kendala dalam mengelola properti daerah. Penelitian ini menggunakan metode deskriptif kualitatif dan dilaksanakan di SKPK Pemerintah Kota Banda Aceh. Penelitian ini mengumpulkan data melalui (yaitu observasi, pencatatan dan wawancara). Hasil penelitian ini menunjukkan bahwa pengelolaan kekayaan daerah banda aceh sudah sesuai dengan teori dalam prakteknya, sehingga penerapan sigolabang sangat efektif dalam pengelolaan aset pemerintahan kota banda aceh dan dapat berdampak positif terhadap kinerja pemerintahan kota. Sehingga mendorong tumbuhnya perpajakan daerah yang diikuti dengan faktor-faktor penghambat. Proses implementasi aplikasi ini untuk mendukung keutuhan alat dan infrastruktur infrastruktur Fasilitas internet dan kemampuan masyarakat yang belum terlalu mahir dalam menggunakan aplikasi sigolabang, diharapkan Pemerintah Kota Banda Aceh lebih memperhatikan instansi yang mengelola kekayaan daerah agar dapat melaksanakan tugas dengan lebih baik dan menciptakan pemerintahan yang baik.
\end{abstract}

Kata Kunci: Sigolabang, Pengelolaan BMD, Banda Aceh 


\section{Pendahuluan}

Pengelolaan kekayaan daerah berhasil dalam mengelola perekonomian daerah. Berdasarkan prinsip pengelolaan yang efektif dan efisien, pengelolaan aset yang tepat dan efektif sangat bermanfaat dan dapat memberikan kontribusi bagi pembangunan masyarakat di daerah tersebut. Dengan mengedepankan prinsip tata kelola yang baik, pengelolaan aset yang profesional dan modern dapat meningkatkan kepercayaan masyarakat terhadap pemerintah daerah itu sendiri. (Pratama 2016).

Pengelolaan kekayaan daerah juga diatur dalam Undang-Undang Nomor 1 tentang Keuangan Negara Tahun 2004. Pasal 44 undang-undang ini berisi "mewajibkan pengguna properti dan / atau pengguna properti untuk mengelola dan mengelola negara bagian / daerah di bawah kendali terbaiknya. Properti". Kepala daerah adalah penguasa yang bertanggung jawab penuh, pemimpin daerah tidak hanya harus merumuskan kebijakan, tetapi juga bagaimana bertanggung jawab dalam pengelolaan BMD, harus benar-benar profesional dan transparan, agar tidak berdampak negatif terhadap laporan keuangan pemerintah daerah.

Pengelolaan kekayaan daerah merupakan bagian dari sistem, sistem akuntansi, yang merupakan bagian dari sistem informasi manajemen. Menurut S.P. Harining (2006) dalam Ansari (2016) Sistem dirancang untuk memperoleh informasi yang berguna bagi pemangku kepentingan atau lembaga. Berdasarkan uraian di atas, pengelolaan kekayaan daerah adalah untuk mengetahui status BMD suatu tempat. Jika informasi yang diperoleh dalam pengelolaan BMD mencukupi maka informasi tersebut valid.

Pemerintah daerah harus mampu mengelola BMD semaksimal mungkin agar aset tersebut menjadi bagian penting dalam perekonomian dan keuangan daerah berkembang. Namun jika kapabilitasnya tidak kuat, mengingat BMD juga membutuhkan banyak dana untuk pemeliharaan dan pemeliharaan, hal ini akan menjadi masalah bagi daerah. Selain itu, setiap aset juga menghadapi tantangan yang berbeda, sehingga perlu tata kelola yang baik dan harus mengikuti SOP yang dilaksanakan oleh semua pihak terkait baik pemerintah pusat maupun daerah. Oleh karena itu, pengelolaan BMD harus mengikuti peraturan lengkap yang mencakup aspek-aspek penting dalam pengelolaan keuangan yang prudent. Numun tidak menutup kemungkinan daerah di mana inovasi dilakukan dalam model yang baik berdasarkan karakteristik daerah dan kearifan lokalnya. (Saeli, 2011) 
100 | Helmi, Adi, Effendi Analisis Penggunaan Aplikasi...

Aset daerah merupakan bagian dari penyusunan rencana awal daerah, komponen asset tetap masuk dalam asset tetap dan bahkan tetmasuk barang yang bersifat persediaan, sebagaimana dimasukkan dalam neraca daerah, perencanaan yang baik dapat dilakukan oleh pemerintan kota banda Aceh dengan melakukan sebuah perencanaan yang matang dan melibatkan sumber daya manusia yang mampu dibidangnya, sehingga laporan keuangan tidak menjadi permasalahan dikemudian hari, akan tetapi kekurangan SDM dan fsilitas akan berdampak terhadap kinerja pemerintah dalam pengelolaan asset yang baik (Simamora 2012)

Pemerintah dalam mengembangkan asset dengan mengunakan teknologi merupakan sebuah tuntutan baik pelayan, transparansi dan pengelolaan sehingga pemerintah harus mengedepankan teknologi yang menjadi bahan pendukung untuk mengelola dengan rapi, E-giverment juga merupakan bagian penting terhadap pemerintah dalam memerankan tugas pokoknya untuk mencapai kesempurnaan dalam mengelola.

Seiring berjalannya waktu, pemerintah ditunjuk untuk terus berinovasi melaksanakan rencananya agar cepat, berkualitas, transparan dan akuntabel. Salah satunya sejak era 4.0 Information Technology diciptakan untuk mempermudah pekerjaan dan pengelolaan, teknologi diterapkan dalam setiap kegiatan pemerintahan. Berbagai jenis teknologi telah mengembangkan dan mengubah paradigma sistem interaktif dan manusia. Dalam hal ini, Banda Aceh tidak mau ketinggalan dalam penerapan teknologi informasi yang disebut dengan e-government dalam pengelolaan harta benda milik daerah, dan disebut dengan aplikasi SIGOLABANG (sistem ringkasan pengelolaan kekayaan daerah). Penulis meyakini bahwa sistem ini menjadi tolak ukur pemerintah dalam keberhasilan pengelolaan kekayaan daerah di Banda Aceh.

\section{Tinjauan Pustaka}

Dalam Azhar 2017, Masdisasmo mencontohkan, terkait peningkatan kewenangan pengelolaan satelit nasional, panda perlu menyiapkan perangkat yang tepat mulai dari perencanaan, pengelolaan / pemanfaatan hingga akuntabilitas dan pengawasan, serta bertanggung jawab secara proporsional, transparan, dan efektif serta efektif Manajemen aset daerah. 


\section{Teori manajemen asset}

Pengelolaan aset sangat penting karena akan mendukung pelaksanaan tanggung jawab dan fungsi instansi pemerintah, alasannya untuk memperkuat status hukum setiap tanah dan bangunan yang seringkali dijaga dan dipantau oleh penanggung jawab pengelolaan aset.

Pengelolaan BMD adalah segala kegiatan yang meliputi persyaratan perencanaan dan penggunaan, penggunaan, anggaran keselamatan dan pemeliharaan, evaluasi pengalihan, serta pedoman pengawasan dan pengendalian.Dalam rangka melaksanakan kinerja pemerintahan dalam pengelolaan BMD, Pemerintah Kota Banda Aceh akan melaksanakan dengan baik sejak awal perencanaan yang matang. Tanggung jawab.

Melalui melakukan beberapa kegiatan untuk mengelaborasi tentang perlunya BMD mengaitkan pembelian barang di masa lalu dengan pembelian yang sedang berjalan sebagai dasar pelaksanaan tindakan ke depan, salah satunya adalah Pemerintah Banda Aceh yang telah melakukan laporan kepada SKPK. Mensosialisasikan pelatihan pengelolaan BMD untuk memaksimalkan hasil dari indikator yang ingin dicapai. Pemerintah juga telah dimatikan agar lebih inovatif dalam melaksanakan rencana kebijakannya, salah satunya dengan memprioritaskan sistem e-government dalam melaksanakan tugas keagenan untuk mendorong kinerja peralatan.

\section{Teori E-Government}

E-government adalah pengelolaan pemerintahan berbasis teknologi informasi yang bertujuan untuk mendukung kinerja pemerintah dan hubungannya dengan publik, swasta, dan pemangku kepentingan terkait untuk mencapai tata kelola pemerintahan yang baik. (Bank Dunia, 2001)

Menurut Center for Democracy and Technology and InfoDev, proses implementasi egovernment dibagi menjadi tiga (tiga) tahap, tiga tahap tersebut antara lain:

1. Release, yaitu menggunakan teknologi untuk memberikan akses yang luas kepada publik terhadap informasi dan informasi pemerintah Ketersediaan. Informasi yang dapat diperoleh di situs web instansi pemerintah akan menimbulkan kepercayaan publik kepada pemerintah, dan kemudahan memperoleh informasi merupakan salah satu tanda adanya iklan elektronik. Hal yang sama dijelaskan dalam teori agarwal. 
2. Interaksi Hal ini menuntut masyarakat untuk berpartisipasi dalam setiap kegiatan pemerintahan, salah satunya adalah menyediakan jaringan yang memungkinkan terjalinnya hubungan yang saling menguntungkan dengan masyarakat. Dan menjalin hubungan langsung dengan lembaga lain.

3. Bertransaksi, yang menjamin ketersediaan layanan online untuk menjalin interaksi dengan publik dan interoperabilitas dengan aplikasi dan data lembaga lain. Untuk mewujudkan hal tersebut tentunya harus diperoleh komitmen dari pimpinan pemerintah daerah.

Kajian-kajian sebelumnya terkait kajian ini antara lain: Raharja, Dkk 2015 menulis tentang keuangan daerah dan pengelolaan aset.Kajian kasus dilakukan di Bagian Administrasi Keuangan dan Aset Daerah Kabupaten Ramungen. Dikelola. Operasional BPKD Lamongan kurang memuaskan, masih terdapat kendala dalam pengelolaannya, keterbatasannya adalah pembahasan rencana pendapatan dan belanja daerah yang tidak tepat oleh legislatif dan kurangnya sumber daya manusia yang berlatar belakang akuntansi.

Persamaan antara penelitian ini dengan penulis adalah sama-sama telah mempelajari pengelolaan kekayaan daerah, namun perbedaan yang mendasar adalah penelitian ini tidak secara khusus mengkaji penggunaan aplikasi sebagai media pengelolaan kekayaan daerah, dan penulis lebih spesifik mengadopsi. Gunakan teknologi atau aplikasi untuk mengelola properti daerah. Secara spesifik, Sigolabang juga berbeda dengan permasalahan yang diangkat dalam penelitian ini. Kerugiannya tidak mempertimbangkan kerangka dasar ideologis dan tidak dapat menjelaskan proses pelaksanaan keuangan daerah dan pengelolaan aset di bidang tersebut.Oleh karena itu proses dan hasil masih belum Bagus, tapi secara keseluruhan bagus.

Studi kedua dilakukan oleh Hasfi et al. Pada tahun 2013. Judul penelitian ini adalah "Penelitian di Dinas Perpajakan, Keuangan, dan Manajemen Aset Kabupaten sintang". Hasil penelitian ini menunjukkan bahwa pengelolaan barang milik daerah DPPKA Kabupaten sintang belum sepenuhnya terlaksana. Hal tersebut meliputi kebutuhan perencanaan dan anggaran, pengadaan, penerimaan dan distribusi, penggunaan, pengelolaan, keselamatan dan pemeliharaan, pemanfaatan, evaluasi dan pemusnahan aset daerah yang tidak memenuhi kebutuhan organisasi, sehingga mengakibatkan inefisiensi dan pemborosan.

Persamaannya dengan penelitian ini adalah pada pengelolaan kekayaan daerah, namun yang membedakan dari penelitian ini adalah penelitian ini masih sangat umum, 
sehingga hasil penelitian juga menunjukkan bahwa penulis kurang memperhatikan permasalahan spesifik yang diangkat, sehingga pembaca tidak bisa. Jawabannya menarik kesimpulan konkret. Masalah dipelajari, tetapi secara keseluruhan, studi ini baik dari sudut pandang teoritis dan sistematis.

Ketiga, Monica et al. (2017) mengkaji Sistem Informasi Manajemen Daerah (SIMDA) untuk aset daerah pada lembaga keuangan dan pengelolaan aset daerah di Kota Manado.Menurutnya, instansi pemerintah merupakan pengelola dan pengelola Pengguna anggaran wajib melakukan pengelolaan keuangan untuk menjelaskan tugas pokoknya. Fungsinya berdasarkan rencana yang ditentukan oleh masing-masing instansi. Hasil kajian menunjukkan bahwa penerapan sistem informasi manajemen daerah pada Biro Keuangan dan Pengelolaan Aset Daerah Kota Manado sangat Membantu pemerintah daerah untuk mengelola kekayaan daerah. Dan SIMDA juga memberikan instruksi lengkap, yang dapat dilihat pada keluaran hasil, dan laporan dapat dibuat dengan cepat. Aplikasi SIMDA tidak kompatibel saat dibuka di Windows 10, sehingga SIMDA susah diakses.

\section{Metode Penelitian}

Penelitian ini mengunakan Metode penelitian Kualitatif deskriptif Penelitian ini dilakukan di SKPK pemerintah kota Banda Aceh, pengumpulan data melalui data pirmer dan data sekunder yaitu melalui observasi, dokumentasi dan wawancara.( Sugiono, 2011)

\section{Pembahasan}

\section{Pengunaan Aplikasi Sigolabang dalam Pengelolaan Barang Milik Daerah Kota Banda Aceh}

Proses pengelolaan BMD dengan menggunakan aplikasi Sigolabang merupakan bagian penting dari pelaksanaan kegiatan pengelolaan keuangan daerah. Oleh karena itu, pengelola properti daerah perlu terorganisir dengan baik. Salah satu peraturan yang menjadi dasar pengelolaan kekayaan daerah Banda Aceh qanun No. 7 Tahun 2018 yang mengatur tentang pengelolaan kekayaan daerah Banda Aceh. Dalam melaksanakan tugas pemerintah kota mengunakan teknologi yang berbentuk aplikasi sehingga prosesnya lebih transparan, tertata dan lebih rapi, walikota sebagai pemegang kekuasaan telah menyusun dan menyetujui alur proses pengunaan aplikas sigolabang ini sebagai wadah dalam mengelola asset daerah. 
104 | Helmi, Adi, Effendi Analisis Penggunaan Aplikasi...

Pemerintah kota Banda Aceh dalam menjalankan tugasnya telah melalui alur yang baik secara kelembagaan sehingga tugas dan tanggung jawab sangat jelas untuk masing-masing lembaga, sebagaiman dalam organisasi selain ada peraturan dan SOP yang harus dipatuhi teapi juga ada alur bagan yang telah didesain untuk medapatkan hasisl yang baik dalam mengelolaat asset ini.

Gambar 1.1

Alur proses pengunaan aplikasi Sigolabang dalam pengelolaan BMD Kota BAanda Aceh

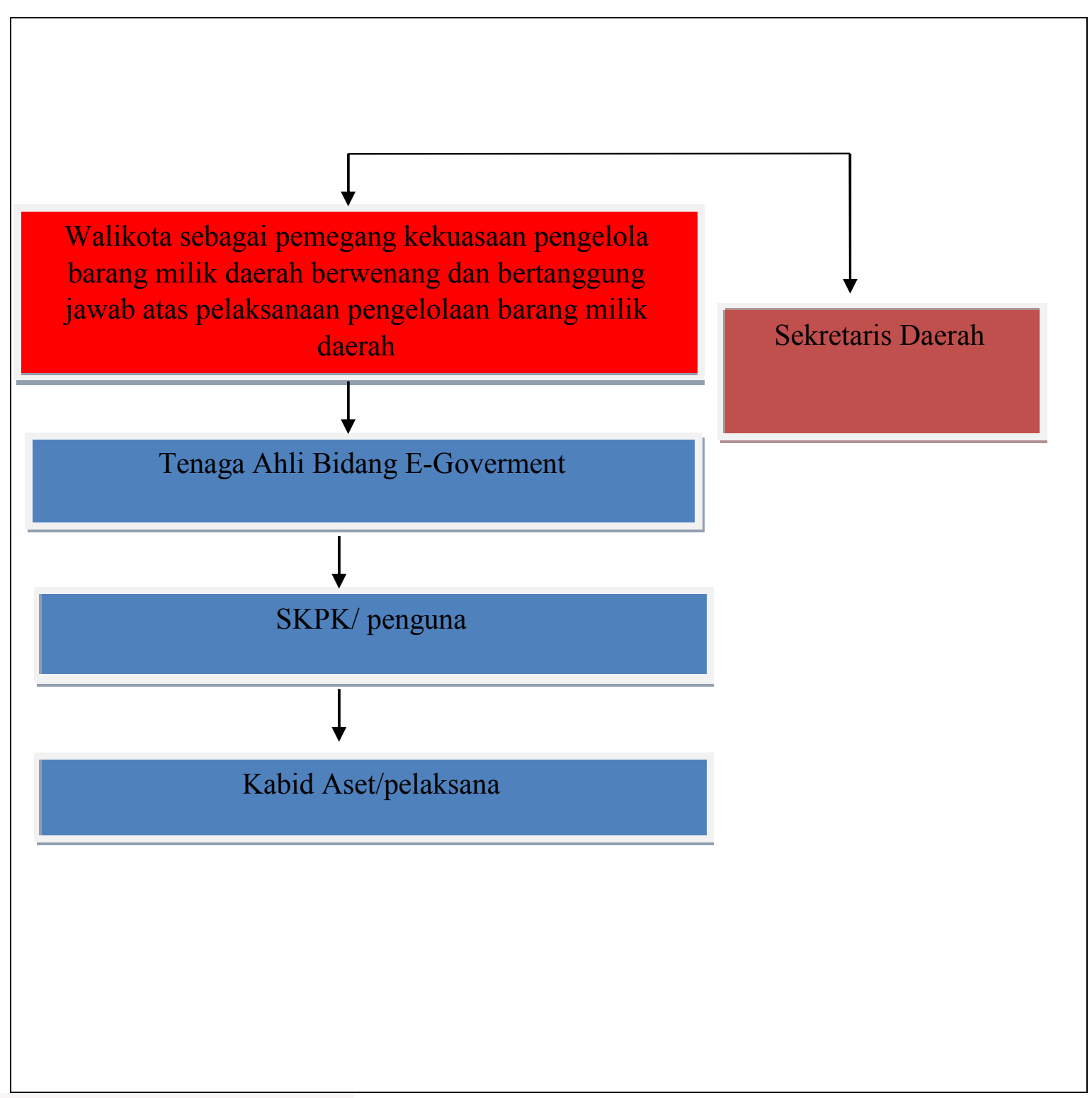

Sumber: Data diolah 2020 
Berdasarkan gambarr diatas dapat dilihat proses aluran pelaksanaan pengelolaan asset daerah dikota banda Aceh. Penggunaan aplikasi Sigolabang untuk pengelolaan barang milik daerah diawali dengan perencanaan Walikota. Walikota dibantu sekretaris daerah untuk mengelola barang milik daerah, yang dilaksanakan oleh SKPK yang dibantu tenaga ahli pemerintahan, dalam pengelola aset di masing-masing instansi. meski tanggung jawab tentu berbeda di berbagai tingkatan, dalam hal kepemilikan daerah, penyimpanan, interaksi dan koordinasi barang antar instansi tetap dalam kondisi baik. Implementasinya adalah sebagai berikut:

1. Proses perencanaan kebutuhan properti daerah Banda Aceh dilakukan oleh walikota melalui koordinasi dan kerjasama seluruh SKPK dan SKPK, sehingga perencanaan kebutuhan properti daerah Banda Aceh dilakukan musyawarah. Hal ini dilakukan atas dasar agar detail kebutuhan dapat berjalan dengan baik.

2. SKPK sebagai pengguna aplikasi sigolabang mengelola kekayaan daerah sesuai dengan tanggung jawab dan tanggung jawab masing-masing instansi dalam pengelolaan kekayaan daerah Banda Aceh, sehingga dapat bermanfaat bagi pemerintah daerah dan menghimpun potensi pendapatan asli daerah dan nilai kekayaan bersih.

3. SKPK yang bertanggung jawab atas pekerjaan inventarisasi di Pemerintah Kota Banda Aceh telah melakukan tugasnya dengan baik. Namun dalam pengelolaan properti kawasan tersebut, Pemerintah Kota Banda Aceh memiliki beberapa SKPK untuk melakukan inventarisasi secara manual, namun masih berlaku sebagai referensi Regulasi. Tujuannya adalah untuk menyediakan data rinci terkini tentang harta benda daerah, antara lain kuantitas / kuantitas fisik, spesifikasi, kondisi (baik / rusak ringan / rusak berat), dll., Dan mencatatnya dalam "Daftar Barang Milik Daerah" sehingga dapat mendukung aset tetap dalam laporan. Validitas nilai. Keuangan pemerintah daerah

4. Pemerintah Kota Banda Aceh dapat mengetahui keberadaan dan status kekayaan daerah, serta menentukan pemanfaatan dan optimalisasi kekayaan daerah yang dapat dioptimalkan dengan pemanfaatan kekayaan daerah untuk perencanaan penentuan kebutuhan, penganggaran, pengadaan, penyimpanan dan distribusi, pemeliharaan, dan penghapusan. / Atau potensi. , Mengontrol, mengotorisasi / memanfaatkan dan melindungi properti area. 
5. Sekretaris Pemerintah Kota Banda Aceh juga berharap agar tim BMD dan seluruh SKPK di lingkungan Pemerintah Kota Banda Aceh serius melaksanakan kegiatan ini, karena melalui kegiatan ini dapat mengetahui keberadaan dan kondisi harta benda setempat. Dan menentukan efektivitas penggunaan dan penggunaan. / Atau potensi kekayaan daerah dapat dioptimalkan dengan menggunakan kekayaan daerah.

6. Pengelolaan properti daerah yang baik dapat digunakan untuk perencanaan yang menentukan permintaan, anggaran, pembelian, penyimpanan dan distribusi, pemeliharaan, penghapusan, pengendalian, otorisasi / pemanfaatan dan keamanan properti daerah.

Pemerintah Kota Banda Aceh mengacu pada teori e-government dan menerapkan pengelolaan properti daerah berdasarkan teori tersebut. Hasil penelitian menunjukkan bahwa mereka telah mendirikan situs di instansi pemerintahan, yaitu menggunakan aplikasi Sigolabang sebagai media utama untuk pengelolaan produk, untuk tahap promosi. siap. Daerah memiliki aplikasinya, dan masing-masing SKPK akan menggunakan aplikasi tersebut sebagai pengguna aplikasi sigolabang sesuai tugas pokoknya masing-masing. Terkait aset daerah, Pemerintah Kota Banda Aceh juga telah menyiapkan SDM yang berbakat di bidang teknis, oleh karena itu setiap pejabat yang mengelola aset tersebut harus mendapatkan pelatihan dan FGD. Sebelum melaksanakan rencana tersebut, mereka juga memasang iklan ke instansi pemerintah dan masyarakat. (Bastien, 2003)

Sesuai amanat Peraturan Pemerintah Nomor 27 Tahun 2014, Menteri Dalam Negeri merumuskan kebijakan dan mengarahkan pengelolaan kekayaan daerah untuk memperkuat tugas Permendagri Nomor 19 Tahun 2016 tentang pedoman pengelolaan kekayaan daerah, dan meningkatkan pemahaman lembaga pengelolaan keuangan Banda Aceh. Melalui bagian aset, sosialisasi dan bimbingan teknis seluruh pengelola SKPD di lingkungan Pemerintah Kota Banda Aceh.

Poin kedua: Pemerintah Kota Banda Aceh juga berinteraksi yang memberikan kesempatan kepada masyarakat untuk ikut serta dalam mensukseskan pelaksanaan rencana pengelolaan barang milik daerah, transparansi partisipasi pemerintah dalam pengelolaan barang milik daerah, sehingga tujuan tata kelola yang baik dapat segera tercapai. Selain itu Pemerintah Kota Banda Aceh juga melakukan kerjasama antar instansi.Dengan membentuk aplikasi khusus dengan BPN maka Pemerintah Kota Banda 
Aceh sangat mudah dalam berinteraksi antar instansi, sehingga penggunaan aplikasi sigolabang dapat efektif. Mengelola barang milik Pemerintah Kota Banda Aceh.

Ketiga, dalam pelaksanaan transaksi poin, Pemerintah Kota Banda Aceh menyediakan layanan berbasis jaringan antara masyarakat dan lembaga untuk memudahkan akses masyarakat dalam merespon layanan mereka. Pemko menyadari bahwa teknologi informasi telah menjadi paradigma yang hidup dalam masyarakat yang interaktif. Banda Aceh terus melakukan terobosan dalam memberikan pelayanan dengan mengutamakan teknologi informasi e-government.Meski tidak seideal Ibu Kota Banda Aceh, namun Pemprov Aceh telah meraih berbagai penghargaan dalam dan luar negeri atas penerapan e-government. Saat ini Pemkot memiliki katalog aplikasi layanan online. Pada direktori berbasis website ini pemerintah memberikan berbagai informasi kepada publik, dan pada kategori ini terdapat beberapa aplikasi berbasis publik yang dapat diakses oleh publik, dan beberapa aplikasi berbasis privat, Informasi apa saja yang disediakan oleh Pemko Banda Aceh. Website ini terbagi menjadi dua kategori, yaitu aplikasi berbasis publik dan aplikasi berbasis privat. Saat ini, pemerintah kota memiliki 80 situs resmi, yang mencakup semua kantor dan lembaga di lingkungan pemerintah kota. Sebagai bentuk komitmen dan eksistensi dalam memberikan informasi online. (J. Hius, 2020).

\section{Faktor pendukung dan faktor penghambat dalam pengelolaan Barang Milik Daerah Kota Banda Aceh}

Pemerintah kota Banda Aceh memiliki daerah yang sangat stretegis secara geografis, sehingga aset pemerintah sangat mudah untuk didata, tidak sulit bagi pemerintah untuk melaksanakan pengelolaan asset, selain itu sebagian besar asset pemerintah kota Banda Aceh sudah tersertifikasi dengan demikian petugas tidak sulit dalam melakukan sensus atau pencatatan asset, karna asset tersebut tidak banyak memiliki masalah atau sengketa. Kedua; yang perlu kita ketahui adalah pemerintah kota Banda Aceh terkenal dengan kota yang selalu mengedepankan E-Government dalam melayani masyarakat, momen ini menjadi factor pendukung dalam pengelolaan Aset daerah ini dikerenakan para petugas yang ada disetiap Dinas atau SKPK sudah memiliki pengalaman yang handal dalam masalah pengunaan tekhnologi, adapun kendala yang dihadapi disini adalah banyak factor termasuk SOP/UU yang mengatur pengelolaan Aset daerah ini, tetapi paling tidak pengalaman adalah salah satu nilai lebih terhadap aparatur pemerintahan yang dimiliki pemerintah kota Banda Aceh saat ini. Adapun penjelasan lebih rinci sebagai berikut;

1. Jaringan Internet; Kendala yang dihadapi oleh pemerintah kota banda 
Aceh melalui SKPK sebagai penguna aplikasi Sigolabang adalah Jaringan internet, infrastruktur seperti ini sebenarnya harus didukung oleh spek yang besar sehingga petugas dalam melaksanakan tugas tidak menjadi kendala, permasalahan yang seperti ini sebenarnya bukanlah problem yang besar dimana dipemerintah sudah tentu tersedianya anggaran yang besar dan teknisi yang hebat, maka dengan demikian proses pelaksanaan pengelolaan asset daerah ini berjalan dengan baik.

2. Sumberdaya manusia; dalam sebuah lembaga sumberdaya manusia menjadi sebuah indicator suksesnya tugas-tugas organisasi, misalnya dipemerintahan selain didukung oleh infrastruktur yang mampuni Sumberdaya Manusia juga harus mendukung dalam menyukseskan pekerjaan, yang terjadi dibeberapa SKPK Kota Banda Aceh ini adalah kemampuan SDM yang belum terlalu kompeten dalam menyingkronnya tujuan kegiatan pemerintah kota Banda Aceh dengan tujuan EGovernment itu sendiri, mengenai Prosedur juga memiliki hambatan karena tidak semua petugas di dinas memahami prosedur yang ada baik UU ataupun Qanun tentang pelaksanaan pengelolaan asset daerah ini, sehingga para petugas hanya sekedar menjalankan tugas tanpa mempertimbangkan manfaat yang bisa dihasilkan dengan adanya pengelolaan seperti ini.

Seperti dalam teori manajemen yang harus dipahami oleh pemko bahwa sasaran akhir atau tujuan utama pengelolaan asat adalah terjadinya optimalisasi dalam pemanfaatan aset daerah kenyataan sampai saat ini aset daerah masih dikelola seadanya sebatas inventarisasi balaka (pancatatan akuntansi) aset daerah masih di konsultasi dengan arus kas negative di bandingkan dengan sebagai asset yang produktif dan memberikan pendapatan kondisi pemanfaatan terhadap asset daerah tersebut membuktikan bahwa asset daerah sebagai sumber daya local yang menunjukan utilitasnya masih rendah. Belum ada pemahaman pengelolaan asset secara utuh.

Tujuan akhir penglolaan asset dengan mengunakan aplikasi Sigolabang ini ekpekasinya adalah agar Perkembangan asset menjadi produktif dalam pengelolaan, sehingga singkron dengan apa yang dicanangkang oleh walikota pada tahap awal sensus terhadap asset daerah Pemerintah Kota Banda Aceh yang melalui Sekretaris Kota Banda Aceh Ir Bahagia Dipl mengatakan Pemko telah melakukan Sensus Barang Milik Daerah (BMD) Tahun 2019 ini akan difokuskan pada 3 (tiga) golongan barang yaitu Tanah, 
Peralatan dan Mesin (Kendaraan Dinas) dan Gedung/Bangunan. Adapun berdasarkan data Inventaris total jumlah barang milik daerah yang akan kita sensus sebanyak 12.755 unit barang dengan nilai perolehan Rp.4.556.094.892.146,-, yang terdiri dari:

- Tanah sebanyak 2.212 persil senilai Rp3.420.792.655.548,-

- Kendaraan Dinas sebanyak 1.085 unit senilai Rp121.706.213.911,-

- Gedung dan Bangunan sebanyak 9.458 unit senilai Rp993.596.022.687,-

\section{Kesimpulan dan Saran}

\subsection{Kesimpulan}

1. Pemerintah kota banda Aceh dalam mendukung terlaksananya e-Government menuju good governance maka tehknologi dalam lembaga pemerintahan sangat dibutuhkan, sehingga mempermudah aparatur dalam bekerja dan menyingkatkan administrasi yang panjang dalam birokrasi, salah satu solusi yang dibangun pemko dalam melaksanakan pengelolaan barang milik daerah dengan mengunakan aplikasi "sigolabang" Sigolabang adalah sudah menunjukkan sebuah program inovasi pemerintah kota banda Aceh yang transparan dalam mengelola barang milik daerah, sehingga asset daerah sudah terdata dengan baik, pemanfaatan yang berguna untuk pertumbuhan ekonomi dan mudah diakses oleh masyarakat.

2. Pemerintah kota Banda Aceh dalam melaksanakan pengelolaan barang milik daerah masih memilik kedala secara umum di Indonesia yaitu berkaitan dengan sumberdaya manusia yang belum memadai, kebutuhan infrastruktur internet yang belum mendukung secara sempurna serta pengelolaan barang baru hanya sebagai pencataan dan penyimpanan, namun petugas masih lemah dalam menfungsikan barang milik daerah yang kurang produktif menjadi lebih produktif sehingga menjadi nilai tambah dalam pendapatan asli daerah.

\subsection{Saran}

Diharapakan kepada pemerinah kota Banda Aceh untuk memerikan perhatian lebih kepada SKPKyang pengelolaan barang milik daerah, dengan memberikan kesempatan kepada petugas untuk berinovasi dan berkarya lebih giat lagi melalui pelatihan-pelaihan dibidang keahlian baik teori maupun praktis berkaitan dengan profesionalisme petugas dalam mengelola barang milik daerah ini. 
110 | Helmi, Adi, Effendi Analisis Penggunaan Aplikasi...

\section{DAFTAR PUSTAKA}

\section{Buku-buku}

Bastian. Perkembangan E-Government di Indonesia. Sinar harapan 2003

Sugiyono, metode penelitian kualitatif, kuantitatif, alfabeta, Bandung 2011

\section{Jurnal}

Agarwal, P.K., "Portals: the path to everything," Government Technology

Anshari, A., \& Syofyan, E. 2016. Pengaruh pengelolaan barang milik daerah terhadap kualitas laporan keuangan pemerintah kota Padang. Jurnal Riset Manajemen Bisnis dan Publik, 4(1).

Center for Democracy and Technology (CDT) and InfoDev, "E-Government Handbook: Part 1 - The Three Phases of E-Government

Mega Raharja, Pengelolaan Keuangan dan Aset Daerah (studi Pada Badan Pengelolaan Keuangan Dan Aset Daerah Kabupaten Lamongan) Vol 3,No 12015

Hasfi, Pengelolaan Barang Milik Daerah (Suatu Studi Pada Dinas Pendapatan, Pengelolaan Keuangan dan Aset Kabupaten Sintang).Tanjungpura University. 2013

Iqlima Azhar, Pengaruh Sistem Informasi Terhadap Manjemen Aset Pada Pemerintah Kota Banda Aceh, Vol 1, No 2. 2017

Raharja, M. Pengelolaan Keuangan Dan Aset Daerah (Studi pada Badan Pengelolaan Keuangan dan Aset Daerah, Kabupaten Lamongan). Jurnal Administrasi Publik. 2015

Saeli, Analisis Efektivitas Pengelolaan Aset Pemerintah Daerah pada Dinas Pendapatan Pengelola Keuangan dan Aset Daerah Kota Bau-Bau UniversitasTerbuka. 2011

Sepang Gisella Monica, David Paul Elia Saaerang, Sonny Pangerapan;Penerapan Sistem Informasi Manajemen Daerah (SIMDA) Barang Milik Daerah Pada Badan Pengelolaan Keuangan dan Aset Daerah Kota Manado, Vol 12, 2017

Simamora, R., \& Halim, A. 2015. Faktor-faktor yang mempengaruhi pengelolaan aset pasca pemekaran wilayah dan pengaruhnya terhadap kualitas laporan keuangan Pemerintah di Kab. Tapanuli Selatan. Jurnal Ekonomi dan Bisnis,10

S. Arikunto. 2006. Prosedur Penelitian Suatu Pendekatan. Jakarta : Rineka Cipta

Zainal A. Hasibuan, langkah-langkah Strategis dan taktis pengembangan E-Gov Untuk Pemda, vol 32 


\section{Data Internet}

http://www1.worldbank.org/publicsector/egov/defin ition.htm,[online] 3 April 2007.

www.layanan.bandaacehkota.go.id Data Aset Pemerintahan Kota Banda Aceh tahun 20172018

\section{Peraturan Perundang-undangan}

Peraturan Menteri Dalam Negeri Nomor 17 Tahun 2007 tentang Pedoman Teknis Pengelolaan Barang Milik Daerah, Pengelolaan Barang Milik Negara/Daerah Qanun Aceh Nomor 14 Tahun 2017 tentang Pengelolaan Barang Milik Aceh Qanun Kota Banda Aceh Nomor 7 Tahun 2018 Tentang Pengelolaan Barang Milik Daerah 